\title{
Identification of blood meal sources of Lutzomyia longipalpis using polymerase chain reaction-restriction fragment length polymorphism analysis of the cytochrome B gene
}

\author{
Vítor Yamashiro Rocha Soares ${ }^{1 /+}$, Jailthon Carlos da Silva ${ }^{1}$, \\ Kleverton Ribeiro da Silva², Maria do Socorro Pires e Cruz², \\ Marcos Pérsio Dantas Santos ${ }^{3}$, Paulo Eduardo Martins Ribolla ${ }^{4}$, Diego Peres Alonso ${ }^{4}$, \\ Luiz Felipe Leomil Coelho ${ }^{5}$, Dorcas Lamounier Costa ${ }^{1}$, Carlos Henrique Nery Costa ${ }^{1}$
}

\footnotetext{
'Laboratório de Pesquisas em Leishmanioses, Departamento de Medicina Comunitária, Instituto de Doenças Tropicais Natan Portela ${ }^{2}$ Laboratório de Sanidade Animal, Departamento de Morfofisiologia Veterinária, Universidade Federal do Piauí, Teresina, Pl, Brasil ${ }^{3}$ Instituto de Ciências Biológicas, Universidade Federal do Pará, Belém, PA, Brasil ${ }^{4}$ Departamento de Parasitologia, Instituto de Biociências de Botucatu, Universidade Estadual Paulista, Botucatu, SP, Brasil ${ }^{5}$ Instituto de Ciências Biomédicas, Universidade Federal de Alfenas, Alfenas, MG, Brasil
}

An analysis of the dietary content of haematophagous insects can provide important information about the transmission networks of certain zoonoses. The present study evaluated the potential of polymerase chain reactionrestriction fragment length polymorphism (PCR-RFLP) analysis of the mitochondrial cytochrome $B(\mathrm{cytb})$ gene to differentiate between vertebrate species that were identified as possible sources of sandfly meals. The complete cytb gene sequences of 11 vertebrate species available in the National Center for Biotechnology Information database were digested with Aci I, Alu I, Hae III and Rsa I restriction enzymes in silico using Restriction Mapper software. The cytb gene fragment (358 bp) was amplified from tissue samples of vertebrate species and the dietary contents of sandflies and digested with restriction enzymes. Vertebrate species presented a restriction fragment profile that differed from that of other species, with the exception of Canis familiaris and Cerdocyon thous. The $358 \mathrm{bp} \mathrm{fragment}$ was identified in 76 sandflies. Of these, 10 were evaluated using the restriction enzymes and the food sources were predicted for four: Homo sapiens (1), Bos taurus (1) and Equus caballus (2). Thus, the PCR-RFLP technique could be a potential method for identifying the food sources of arthropods. However, some points must be clarified regarding the applicability of the method, such as the extent of DNA degradation through intestinal digestion, the potential for multiple sources of blood meals and the need for greater knowledge regarding intraspecific variations in mtDNA.

Key words: blood meal analysis - cytochrome B - PCR-RFLP

Identification of the food source of arthropods allows a better understanding of the vector dynamics and transmission routes of diseases carried by vectors. It may be the best way to clarify which species are incriminated as zoonosis reservoirs and could therefore indicate better control strategies (Ribeiro 1999).

Traditionally, analysis of the dietary content of haematophagous arthropods has been carried out using immunological techniques (Mukabana et al. 2002b). However, serological methods present two limitations: (i) it is impossible to distinguish species that are phylogenetically close (Silva et al. 2001) and (ii) the analysis is restricted to one group of vertebrates because of the use of species-specific antiserum (Dias et al. 2003, Marassá et al. 2006). Studies have identified a well-preserved DNA sequence in the cytochrome B (cytb) gene, which

doi: 10.1590/0074-0276130405

+ Corresponding author: vyrsoares@gmail.com

Received 16 August 2013

Accepted 25 February 2014 is present in mitochondrial DNA and codes for an electron-transporting protein (Meece et al. 2005). This DNA sequence exhibits few intraspecies variations, but sufficient interspecies variations, thereby increasing its specificity. Thus, a large number of hosts may be analysed using universal primers and phylogenetically close species may be distinguished using a molecular test based on the cytb gene (Boakye et al. 1999, Chow-Shaffer et al. 2000, Lee et al. 2002, Meece et al. 2005, Steuber et al. 2005, Muturi et al. 2011, Garlapati et al. 2012, Tiwananthagorn et al. 2012, Pettersson et al. 2013).

The aim of the present study was to provide theoretical validation for using PCR-RFLP of the $c y t b$ gene as a technique to discriminate the blood meal source of Lutzomyia longipalpis. The restriction fragment profiles of some vertebrate species identified as possible sandfly food sources were analysed. It was found that the species could be differentiated according to the sizes of the restriction fragments.

The mitochondrial $c y t b$ gene fragments of the 11 species used in this study (Homo sapiens - HOSA, Rattus norvegicus - RANO, Didelphis marsupialis - DIMA, Canis familiaris - CAFA, Felis catus - FECA, Sus domesticus - SUDO, Bos taurus - BOTA, Gallus gallus - GAGA, Equus caballus - EQCA, Cerdocyon thous - CETH and Pseudalopex 
vetulus - PSVE) were amplified in silico using the primers BM1 (5'CCCCTCAGAATGATATTTGTCCTCA3') and BM2 (5'CCATCCAACATCTCAGCATGATGAAA3') and Basic Local Alignment Search Tool software, which is available from the National Center for Biotechnology Information (GenBank). The sequence of the expected product (358 bp) was species-specific and the Aci I, Alu I, Hae III and Rsa I restriction sites were identified using Restriction Mapper software. The restriction profiles of the fox species $P$. vetulus and $C$. thous were the only two that were not analysed because it was not possible to identify the 358 bp cytb fragment in these species in GenBank. Each species had a restriction fragment profile that was distinct from the others. Thus, these profiles rep-

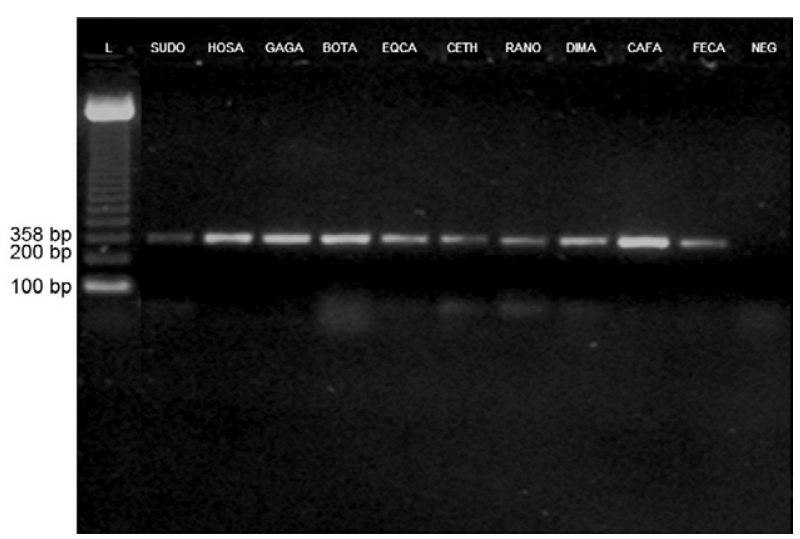

Fig. 1: electrophoresis with polymerase chain reaction on the DNA extracted from peripheral blood and tissue samples from the vertebrate species amplified using the BM1 and BM2 primers (fragment of mitochondrial $c y t b \cong 358 \mathrm{bp}$ ). L: DNA Leader $100 \mathrm{bp}$; NEG: negative control. resented a unique "fingerprint", which could be an important method for distinguishing between each species.

Biological samples (peripheral blood or cellular tissue) of the vertebrate species were collected and DNA was extracted. The mitochondrial $c y t b$ gene fragment (358 bp) was amplified using the BM1 and BM2 primers following the protocol of Meece et al. (2005) (Fig. 1). However, PSVE presented a unique problem: the polymerase chain reaction (PCR) amplified not only the 358 bp fragment, but also a fragment of approximately 615 bp. This fox species is rare and threatened, lives mainly in the central part of Brazil and was excluded from the study (Costa \& Courtenay 2003). However, the presence of these two bands allowed for the differentiation of PSVE from the other animals.

The amplified fragments were sequenced to determine the degree of conservation of the $c y t b$ gene. Comparing the sequenced loco-regional samples with the deposited GenBank sequences, most species presented few mismatches, with no compromised restriction sites and with degrees of similarity greater than $98 \%$ (Table I). There were no changes in the restriction sites of CAFA, HOSA, GAGA, RANO, SUDO or BOTA. However, EQCA and FECA gained $A c i$ I and $R s a$ I restriction sites, respectively and DIMA lost two Alu I restriction sites (Table I, Supplementary data). Because the number of $c y t b$ sequences deposited in GenBank is limited, sequencing of this fragment in loco-regional host species becomes important for analysis using the PCR-restriction fragment length polymorphism (RFLP) technique. As $c y t b$ sequences continue to be deposited into these genetic databases and as the variations in mtDNA become better understood, sequencing of this fragment from loco-regional host species will be needed less frequently, thus reducing costs and increasing the applicability of the method.

TABLE I

Identification of the species that were candidates as possible food sources for sandflies

\begin{tabular}{|c|c|c|c|c|}
\hline Species & Common name & $\begin{array}{c}\text { Access } \\
(\mathrm{BLAST} / \mathrm{NCBI})\end{array}$ & $\begin{array}{c}\text { Similarity } \\
\text { GenBank/Regional } \\
(\%)\end{array}$ & $\begin{array}{l}\text { Changes in } \\
\text { restriction } \\
\text { sites }\end{array}$ \\
\hline Homo sapiens (HOSA) & Human & AY509658 & 99 & 0 \\
\hline Rattus norvegicus (RANO) & Rats & AB033713 & 98 & 0 \\
\hline Didelphis marsupialis (DIMA) & Opossum & DMU34665 & 97 & -2 \\
\hline Canis familiaris (CAFA) & Dog & DQ309764 & 100 & 0 \\
\hline Felis catus (FECA) & Domestic cats & AY509646 & 99 & +1 \\
\hline Sus domesticus (SUDO) & Pig & AY534296 & 99 & 0 \\
\hline Bos taurus (BOTA) & Cattle & AY682380 & 99 & 0 \\
\hline Gallus gallus (GAGA) & Hens & AY509649 & 100 & 0 \\
\hline Equus caballus (EQCA) & Horse & AY819736, AY819737 & 99 & +1 \\
\hline Cerdocyon thous (CETH) & Crab-eating fox & AF028169 & $83^{a}$ & Unparsed \\
\hline Pseudalopex vetulus (PSVE) & Hoary fox & EF106996 & - & Unparsed \\
\hline
\end{tabular}

$a$ : the sequenced fragment of cytochrome B gene had a 99\% affinity with the Canis familiaris from GenBank; BLAST: Basic Local Alignment Search Tool; NCBI: National Center for Biotechnology Information. 

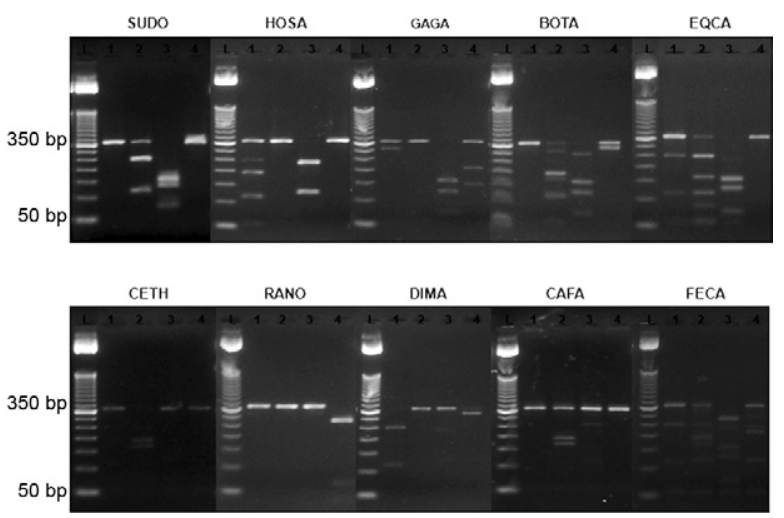

Fig. 2: polymerase chain reaction-restriction fragment length polymorphism on the DNA samples of interest amplified using the BM1 and BM2 primers and digested using Aci I, Alu I, Hae III and Rsa I (fragment of mitochondrial $c y t b \cong 358 \mathrm{bp}$ ). L: DNA Leader $50 \mathrm{bp} ; 1$ : Aci I; 2: Alu I; 3: Hae III; 4: Rsa I.
To confirm the in silico analysis, the PCR products were submitted to enzymatic digestion using the Aci I, Alu I, Hae III and Rsa I enzymes. The restriction profiles of the species studied are shown in Fig. 2 and Table II. In practice, the restriction pattern of Aci I showed the expected fragments (244 bp and $113 \mathrm{bp}$ ) for DIMA, FECA and EQCA. Regarding the DNA of HOSA, a 244 $\mathrm{bp}$ band was found in addition to the expected fragments (189 bp, $113 \mathrm{bp}$ and $55 \mathrm{bp}$ ). The expected restriction pattern of GAGA was observed; however, the $49 \mathrm{bp}$ fragment could not be visualised because of its small size. The $A c i$ I endonuclease did not cut the DNA of CAFA, BOTA, SUDO, RANO or CETH.

When the DNA samples were digested with Alu I enzymes, the expected restriction fragments for SUDO (242 bp and $115 \mathrm{bp}$ ) and BOTA (190 bp, $114 \mathrm{bp}$ and $53 \mathrm{bp}$ ) were confirmed. However, BOTA presented an additional nonspecific fragment (304 bp). No Alu I restriction site

TABLE II

Restriction profiles of the species of interest using the mtDNA 358 bp fragment

\begin{tabular}{|c|c|c|c|c|}
\hline \multirow[b]{2}{*}{ Host species } & \multicolumn{4}{|c|}{ Restriction enzymes (cleavage sites) } \\
\hline & $\begin{array}{c}A c i I \\
\mathrm{CC} \downarrow \mathrm{GC}\end{array}$ & $\begin{array}{c}\text { Alu I } \\
\mathrm{AG} \downarrow \mathrm{CT}\end{array}$ & $\begin{array}{l}\text { Hae III } \\
\mathrm{GG} \downarrow \mathrm{CC}\end{array}$ & $\begin{array}{c}R s a I \\
\mathrm{GT} \downarrow \mathrm{AC}\end{array}$ \\
\hline \multicolumn{5}{|l|}{ Homo sapiens (HOSA) } \\
\hline Sequenced & $189 ; 113 ; 55$ & 358 & $233 ; 124$ & 358 \\
\hline NCBI (AY509658) & $188 ; 114 ; 55$ & 358 & $232 ; 125$ & 358 \\
\hline \multicolumn{5}{|c|}{ Rattus novergicus (RANO) } \\
\hline Sequenced & 358 & 358 & 358 & $267 ; 59 ; 31$ \\
\hline NCBI (AB033713) & 358 & 358 & 358 & $267 ; 59 ; 31$ \\
\hline \multicolumn{5}{|c|}{ Didelphos marsupialis (DIMA) } \\
\hline Sequenced & $244 ; 113$ & 358 & 358 & $326 ; 31$ \\
\hline NCBI (DMU34665) & $244 ; 133$ & $272 ; 69 ; 16$ & 358 & $326 ; 31$ \\
\hline \multicolumn{5}{|c|}{ Canis familiaris (CAFA) } \\
\hline Sequenced & 358 & $190 ; 167$ & 358 & 358 \\
\hline NCBI (DQ309764) & 358 & $190 ; 165$ & 358 & 358 \\
\hline \multicolumn{5}{|l|}{ Felis catus (FECA) } \\
\hline Sequenced & $244 ; 113$ & $190 ; 120 ; 47$ & $272 ; 74 ; 11$ & $214 ; 119 ; 24$ \\
\hline NCBI (AY509646) & $243 ; 114$ & $189 ; 120 ; 48$ & $273 ; 73 ; 11$ & $213 ; 144$ \\
\hline \multicolumn{5}{|l|}{ Sus domesticus (SUDO) } \\
\hline Sequenced & 358 & $242 ; 115$ & $153 ; 130 ; 74$ & 358 \\
\hline NCBI (AY534296) & 358 & $242 ; 115$ & $153 ; 130 ; 74$ & 358 \\
\hline \multicolumn{5}{|l|}{ Bus taurus (BOTA) } \\
\hline Sequenced & 358 & $190 ; 114 ; 53$ & $159 ; 124 ; 74$ & $322 ; 31 ; 4$ \\
\hline NCBI (AY682380) & 358 & $190 ; 169$ & $159 ; 126 ; 74$ & $322 ; 33 ; 4$ \\
\hline \multicolumn{5}{|l|}{ Gallus gallus (GAGA) } \\
\hline Sequenced & $308 ; 49$ & 358 & $159 ; 124 ; 74$ & $208 ; 149$ \\
\hline NCBI (AY509649) & $309 ; 48$ & 358 & $159 ; 125 ; 73$ & $209 ; 148$ \\
\hline \multicolumn{5}{|l|}{ Equus caballus (EQCA) } \\
\hline Sequenced & $244 ; 113$ & $160 ; 85 ; 59 ; 53$ & $159 ; 124 ; 74$ & 358 \\
\hline NCBI (AY819736) & 358 & $160 ; 84 ; 59 ; 54$ & $159 ; 125 ; 73$ & 358 \\
\hline \multicolumn{5}{|c|}{ Cerdocyon thous (CETH) } \\
\hline Sequenced & 358 & $190 ; 167$ & 358 & 358 \\
\hline NCBI (AF028169) ${ }^{a}$ & - & - & - & - \\
\hline
\end{tabular}

$a$ : the prime BM1 did not recognise a sequence of cytochrome B gene; NCBI: National Center for Biotechnology Information. 
was found for DIMA, RANO, GAGA or HOSA. In addition to the expected fragments for EQCA and FECA, unexpected fragments were also observed: $242 \mathrm{bp}$ and 115 bp for EQCA and 237 bp for FECA. CETH and CAFA presented bands of 190 and $167 \mathrm{bp}$, as expected (Fig. 2, Table II). As reported by other authors, nonspecific bands were also visualised in the present study (Zhang \& Hewit 1996, Partis et al. 2000, Steuber et al. 2005). One explanation for this phenomenon could be the coamplification of $c y t b$ pseudogenes. Pseudogenes are nonfunctional copies of mtDNA fragments present in nuclear DNA. However, when the expected fragments are also viewed, identification of the species is not impaired.

Digestion with the Hae III endonuclease allowed differentiation between several species of vertebrates. GAGA and EQCA presented the same pattern of bands (159 bp, $124 \mathrm{bp}$ and $74 \mathrm{bp}$ ); however, BOTA presented an extra fragment (290 bp). SUDO (130 bp, $153 \mathrm{bp}$ and $74 \mathrm{bp}$ ) and HOSA (233 bp and $124 \mathrm{bp}$ ) showed the expected patterns. No Hae III restriction site was found for CAFA, CETH, DIMA or RANO. FECA presented both nonspecific and expected bands (Fig. 2, Table II).

Digestion with the Rsa I enzyme made it possible to differentiate CETH, RANO, GAGA and SUDO from the other host species. The restriction pattern for GAGA was as expected (208 bp and $149 \mathrm{bp}$ ). BOTA and DIMA presented single fragments of $322 \mathrm{bp}$ and $326 \mathrm{bp}$, respectively. Fragments smaller than $31 \mathrm{bp}$ were not visualised. Rsa I did not cut DNA extracted from HOSA, EQCA, SUDO, CETH or CAFA (Fig. 2, Table II).

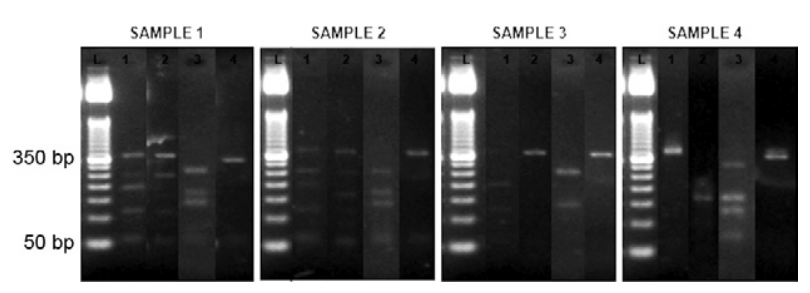

Fig. 3: polymerase chain reaction-restriction fragment length polymorphism on the DNA samples from sandflies amplified using the BM1 and BM2 primers and digested using Aci I, Alu I, Hae III and Rsa $I$ (fragment of mitochondrial $c y t b \cong 358 \mathrm{bp}$ ). L: DNA Leader $50 \mathrm{bp} ; 1$ : Aci I; 2: Alu I; 3: Hae III; 4: Rsa I.
The enzymes Aci I, Alu I, Hae III and Rsa I were sufficient for the differentiation of the species of interest, with the exception of CAFA and CETH, which presented the same restriction profile. A fifth enzyme or other genetic marker could be used to differentiate these two species. This differentiation is of great epidemiological interest because foxes and dogs share an important role as reservoirs of visceral leishmaniasis. As foxes have periurban habitats, this identification method could confirm whether foxes maintain the urban cycle (Costa \& Vieira 2001, Silva et al. 2001).

To verify whether PCR-RFLP of the $c y t b$ gene can be used to evaluate the blood meal source of sandflies, a total of 80 female specimens of $\mathrm{Lu}$. longipalpis were caught in domestic and peridomestic environments using two electrically powered CDC light traps. DNA was extracted from the intestinal contents of sandflies and PCR amplification was performed using BM1 and BM2 primers. The $358 \mathrm{bp}$ fragment of $c y t b$ was identified in 76 samples. Most of the sandflies had blood in their digestive tubes. Initially, this finding enabled analysis by means of sequencing or PCR-RFLP. Of the 76 samples, 10 were chosen randomly and their PCR products were individually digested using four restriction enzymes (Aci I, Alu I, Hae III and Rsa I). In four out of the 10 sandflies, the food sources were assumed (Fig. 3, Table III). The food sources of samples 1 and 2 were believed to be EQCA. The probable food sources of samples 3 and 4 were HOSA and BOTA, respectively. Some fragments could not be identified because of their size or due to the small amount of DNA present. It is possible that the low quantity DNA resulted in weak or even missing band signals, making it difficult to analyse the fragment profile. Theoretically, this technique could become less accurate if DNA was degraded via intestinal digestion (Mukabana et al. 2002a). A detailed analysis of sandflies in the laboratory, using a known food source and performing measurements at specific time points, could resolve this issue.

Therefore, the PCR-RFLP technique has the potential to be useful for phlebotomine blood meal source identification. However, some points must be clarified regarding the applicability of the method, such as the extent of DNA degradation through intestinal digestion, the potential for multiple sources of blood meals and the need for greater knowledge of intraspecific mtDNA variations.

TABLE III

Probable restriction profiles of the sandflies using the mtDNA 358 bp fragment

\begin{tabular}{|c|c|c|c|c|}
\hline \multirow[b]{2}{*}{ Sandflies } & \multicolumn{4}{|c|}{ Restriction enzymes (cleavage sites) } \\
\hline & $\begin{array}{c}A c i I \\
\mathrm{CC} \downarrow \mathrm{GC}\end{array}$ & $\begin{array}{c}\text { Alu I } \\
\mathrm{AG} \downarrow \mathrm{CT}\end{array}$ & $\begin{array}{l}\text { Hae III } \\
\text { GG } \downarrow C C\end{array}$ & $\begin{array}{c}R s a I \\
\mathrm{GT} \downarrow \mathrm{AC}\end{array}$ \\
\hline Sample 1 & $244 ; 180 ; 133 ; 55$ & $242 ; 159 ; 113 ; 55$ & $159 ; 124$ & 358 \\
\hline Sample 2 & $244 ; 180 ; 133 ; 55$ & $242 ; 159 ; 113 ; 55$ & $159 ; 124$ & 358 \\
\hline Sample 3 & $189 ; 113$ & 358 & $233 ; 124$ & 358 \\
\hline Sample 4 & 358 & $190 ; 114$ & $290 ; 159 ; 124 ; 74$ & 322 \\
\hline
\end{tabular}




\section{REFERENCES}

Boakye DA, Tang J, Truc P, Merriweather A, Unnasch TR 1999. Identification of blood meals in heamatophagous Diptera by cytochrome B heteroduplex analysis. Med Vet Entomol 13: 282-287.

Chow-Shaffer E, Sina B, Hawley WA, de Benedicts J, Scott TW 2000. Laboratory and field evaluation of polymerase chain reactionbased forensic DNA profiling for use in identification of human blood meal sources of Aedes aegypti (Diptera: Culicidae). J Med Entomol 37: 492-502.

Costa CHN, Courtenay O 2003. A new record of the hoary fox Pseudalopex vetulus in North Brazil. Mammalia 67: 593-594.

Costa CHN, Vieira JBF 2001. Mudanças no controle da leishmaniose visceral no Brasil. Rev Soc Bras Med Trop 34: 223-228.

Dias FOP, Lorosa ES, Rebêlo JMM 2003. Fonte alimentar sanguínea e a peridomiciliação de Lutzomyia longipalpis (Lutz \& Neiva, 1912) (Psychodidae, Phlebotominae). Cad Saude Publica 19: 1373-1380.

Garlapati RB, Abbasi I, Warburg A, Poché D, Poché R 2012. Identification of blood meals in wild caught blood fed Phlebotomus argentipes (Diptera: Psychodidae) using cytochrome B PCR and reverse line blotting in Bihar, India. J Med Entomol 49: 515-521.

Lee JH, Hassan H, Hill G, Cupp EW, Higazi TB, Mitchell CJ, Godsey MS, Unnasch TR 2002. Identification of mosquito avian-derived blood meals by polymerase chain reaction-heteroduplex analysis. Am J Trop Med Hyg 66: 599-604.

Marassá AM, Consales CA, Galati EAB, Nunes VLB 2006. Identificação do sangue ingerido por Lutzomyia (Lutzomyia) longipalpis (Lutz \& Neiva, 1912) e Lutzomyia (Lutzomyia) almerioi (Galati \& Nunes, 1999) pela técnica imunoenzimática do ELISA de captura no sistema avidina-biotina. Rev Soc Bras Med Trop 39: 183-186.

Meece JK, Reynolds CE, Stockwell PJ, Jenson TA, Christensen JE, Reed KD 2005. Identification of mosquito blood meal source by terminal restriction fragment length polymorphism profile analysis of the cytochrome B gene. J Med Entomol 42: 657-667.
Mukabana WR, Takken W, Killeen GF, Hawley WA, Knols BGJ 2002a. Extent of digestion affects success of amplifying human DNA from blood meals of Anopheles gambiae (Diptera: Culicidae). Bull Entomol Res 92: 233-239.

Mukabana WR, Takken W, Knols BGJ 2002b. Analysis of arthropod blood meals using molecular genetic markers. Trends Parasitol 18: 505-509.

Muturi CN, Ouma JO, Malele II, Ngure RM, Rutto JJ, Mithöfer KM, Enyaru J, Masiga DK 2011. Tracking the feeding patterns of tsetse flies (Glossina Genus) by analysis of blood meals using mitochondrial cytochromes genes. PLoS ONE 6: e17284.

Partis L, Croan D, Guo Z, Clark R, Coldham T, Murby J 2000. Evaluation of a DNA fingerprinting method for determining the species origin of meats. Meat Scie 54: 369-376.

Pettersson E, Bensch S, Ander M, Chirico J, Sigvald R, Ignell R 2013. Molecular identification of blood meals and species composition in Culicoides biting midges. Med Vet Entomol 27: 104-112.

Ribeiro JMC 1999. Vector biology. In RL Guerrant, DH Walker, PF Weller (eds.), Tropical infectious diseases: principles, pathogens and practice, Churchill Livingstone, Philadelphia, p. 124-133.

Silva VC, Gomes RBB, Barral A, Costa CHN 2001. ELISA não diferencia sangue de cão doméstico de sangue de raposa. Rev $S o c$ Bras Med Trop 34: 757.

Steuber S, Abdel-Rady A, Clausen PH 2005. PCR-RFLP analysis: a promising technique for host species identification of blood meals from tsetse flies. Parasitol Res 97: 247-254.

Tiwananthagorn S, Bhutto AM, Baloch JH, Soomro FR, Kawamura Y, Nakao R, Aoshima K, Nonaka N, Oku Y, Katakura K 2012. Zoophilic feeding behaviour of phlebotomine sand flies in the endemic areas of cutaneous leishmaniasis of Sindh province, Pakistan. Parasitol Res 111: 125-133.

Zhang DX, Hewit GM 1996. Nuclear integrations: challenges for mitochondrial DNA markers. Trends Ecol Evol 11: 247-251. 


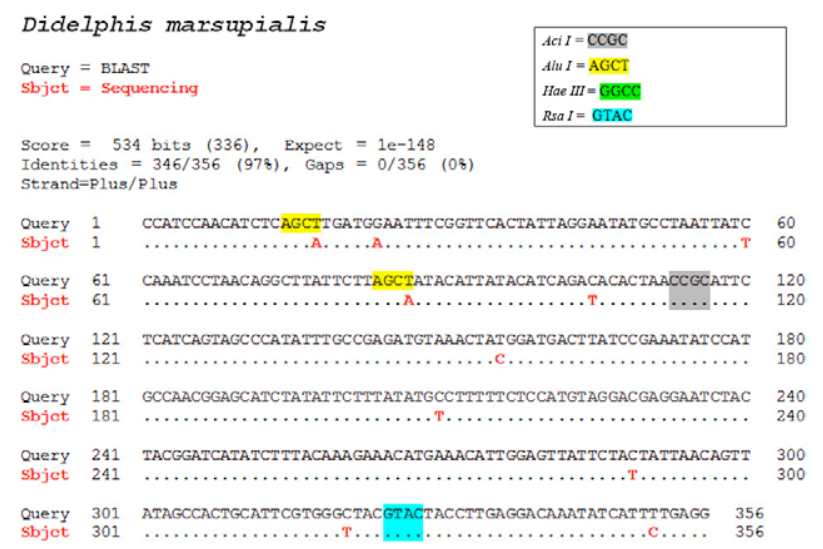

Comparison of the restriction sites between the cytb fragment deposited in GenBank and the sequenced fragment from Didelphis marsupialis. 